\title{
PELANGGARAN PRINSIP KERJA SAMA PERCAKAPAN DALAM ACARA MATA NAJWA DI METRO TV
}

\author{
Afif Setiawan ${ }^{1}$, Rokhmat Basuki ${ }^{2}$, dan Ngudining Rahayu ${ }^{3}$ \\ ${ }^{1,2,3}$ Program Studi Pendidikan Bahasa dan Sastra Indonesia \\ Jurusan Pendidikan Bahasa dan Seni \\ FKIP Universitas Bengkulu \\ afifsetiawan73@yahoo.com
}

\begin{abstract}
Abstrak
Tujuan penelitian ini adalah untuk mendeskripsikan bentuk pelanggaran-pelanggaran prinsip kerja sama percakapan dalam acara Mata Najwa di Metro TV. Metode yang digunakan dalam penelitian ini adalah metode deskriptif kualitatif. Sumber data dalam penelitian ini berupa tuturan Najwa Shihab dan narasumbernya dalam acara Mata Najwa di Metro TV. Data dalam penelitian ini adalah tiga episode dalam acara Mata najwa pada bulan Juni, Agustus, dan Desember yaitu: episode "Kontroversi Luhut" yang tayang pada 1 Juni 2016, "Rupa-Rupa Pengacara" yang tayang pada 31 Agustus 2016, dan episode "Bergerak Demi Hak" yang tayang pada 21 Desember 2016.Teknik pengumpulan data menggunakan metode dokumentasi. Teknik analisis data dalam penelitian ini dilakukan melalui langkah-langkah, yaitu mentranskripsi data, mengidentifikasi data (pengkodean), mengklasifikasi data dalam bentuk tabel, menginterpretasi data, dan menyimpulkan hasil penelitian. Hasil penelitian ditemukan 130 pelangaran prinsip kerja sama percakapan dengan rincian, 56 (43\%) pelanggaran maksim kuantitas, 10 (7,8\%) pelanggaran maksim kualitas, 34 (26,5\%) pelanggaran maksim relevansi, dan 30 (22,6\%) pelanggaran maksim cara. Dalam penelitian ini digolongkan atas dua bentuk pelanggaran prinsip kerja sama percakapan yaitu pelanggaran maksim tunggal dan maksim ganda, dengan rincian 75 tuturan dengan pelanggaran maksim tunggal dan 26 tuturan dengan pelanggaran maksim ganda.. Faktor-faktor yang melatarbelakangi pelanggaran prinsip kerja sama percakapan dalam acara Mata Najwa di Metro TV, yaitu: penaatan maksim kebijaksanaan, maksim kemufakatan, maksim kesederhanaan, maksim kedermawanan, maksim penghargaan, maksim kesimpatian, konsep muka negative dan penyelamatan muka.
\end{abstract}

Kata kunci: Pelanggaran, Prinsip Kerja sama Percakapan, Acara Mata Najwa, Metro TV

\begin{abstract}
The purpose of this study is to describe the form of violations of the principle of cooperation of conversation in the event of Mata Najwa on Metro TV. The method used in this research is descriptive qualitative method. The data source in this research is Najwa Shihab speech and its speaker in Mata Najwa on Metro TV. The data in this study were three episodes of Mata Najwa events in June, August, and December namely: the episode of "Luhut Controversy" which aired on June 1, 2016, "Miscellaneous Lawyers" which aired on August 31, 2016, and the episode "Moves Demi Hak "which aired on December 21, 2016. Data collection techniques use the documentation method. Data analysis technique in this research is done through the steps, that is transcribing data, identifying data (encoding), classifying data in table form, interpreting data, and concluding research result. The results of the study found 130 violations of the principle of conversational cooperation with details,
\end{abstract}


$56(43 \%)$ maxim quantity violations, 10 (7.8\%) maxim quality violations, 34 (26.5\%) maxim relevance breaches, and $30(22.6 \%)$ Violation of the way maxim. In this study, it was classified into two forms of violation of the principle of conversational cooperation, namely the single maxim and multiple maxim violations, with details of 75 utterances with single maximal offenses and 26 speeches with double maxim breaches. Factors behind the breach of the principle of conversational cooperation in Mata Najwa on Metro TV, namely: maximizing wisdom, maxima agreement, maxim of simplicity, maxim of generosity, maxim of appreciation, maxim of conclusion, the concept of negative face and face rescue.

Keywords: Violations, Principles of Conversational Conversations, Mata Najwa, Metro TV

\section{PENDAHULUAN}

Komunikasi dan bahasa merupakan dua hal yang saling terkait satu sama lain. Sebagai mahluk sosial komunikasi merupakan hal yang mutlak dibutuhkan oleh seorang manusia untuk dapat melanjutkan keberlangsungan hidupnya. Untuk dapat berkomunikasi diperlukan suatu alat yang disebut bahasa. Bahasa adalah suatu sistem simbol lisan yang arbitrer yang dipakai oleh anggota suatu masyarakat bahasa untuk berkomunikasi dan berinteraksi sesamanya (Dardjowidjojo, 2005:16). Bahasa merupakan bagian dari kehidupan manusia, karena dalam kehidupan seharihari di manapun dan kapanpun manusia tidak pernah terlepas dari penggunaan bahasa.

Bahasa terdiri dari dua aspek yaitu aspek linguistik dan aspek non-linguistik atau paralinguistik. Kedua aspek ini bekerja sama dalam membangun komunikasi bahasa itu. Aspek linguistik mencakup tataran fonologi, morfologi dan sintaksis. Aspek paralinguistik mencakup kualitas ujaran, unsur suprasegmental (tekanan, nada, dan intonasi), jarak, dan gerak-gerik tubuh. Aspek linguistik dan aspek paralinguistik tersebut berfungsi sebagai alat komunikasi, bersama-sama dengan konteks situasi membentuk atau membangun situasi tertentu dalam proses komunikasi (Chaer, 2010:22).
Suatu komunikasi dalam sebuah percakapan dikatakan berjalan dengan baik apabila tidak terjadi salah penafsiran oleh mitra tutur. Keith Allan (dalam Rahardi, 2005:52) mengemukakan bahwa bertutur adalah kegiatan yang berdimensi sosial. Kegiatan sosial dapat berlangsung baik apabila para peserta pertuturan itu semuanya terlibat aktif di dalam proses bertutur tersebut. Apabila terdapat satu atau lebih pihak yang tidak terlibat aktif dalam kegiatan bertutur dapat dipastikan pertuturan itu tidak dapat berjalan lancar.

Dalam hal ini, agar pesan yang disampaikan dapat diterima dengan baik, perlu adanya suatu kerjasama, yang disebut prinsip kerja sama percakapan. Grice (dalam Wijana, 2009:42) mengemukakan bahwa dalam rangka melaksanakan prinsip kerja sama, setiap penutur haruslah memenuhi 4 maksim percakapan (conversational maxim), yaitu maksim kuantitas, maksim kualitas, maksim relevansi, dan maksim pelaksanaan.

Maksim kuantitas menghendaki agar peserta tutur harus seinformatif mungkin dan tidak berlebihan dalam memberikan informasi yang dibutuhkan oleh mitra tutur. Maksim kualitas menghendaki peserta tutur agar tidak mengatakan sesuatu yang tidak sesuai dengan faktanya. Maksim relevansi menghendaki agar peserta tutur diharapkan relevan terhadap informasi yang diberikan sesuai dengan 
topik percakapan. Maksim cara menghendaki peserta tutur dalam berkomunikasi memberikan informasi yang jelas, dan tidak ambigu.

Dalam fenomena berbahasa di kehidupan sehari-hari, kita sering kali melihat suatu percakapan yang berjalan dengan baik namun tidak jarang pula kita melihat suatu percakapan yang tidak berjalan dengan baik bahkan sampai berakhir dengan kericuhan. Percakapan yang berjalan dengan baik, misalnya saja suatu percakapan antara petugas bank dengan nasabahnya. Petugas bank akan berbicara sebaik mungkin dan seinformatif mungkin agar informasi atau keluhan dari nasabahnya dapat terpenuhi atau diatasi. Begitupun nasabahnya, ia akan memberikan pertanyaan-pertanyaan seefektif mungkin agar informasi yang diinginkan atau masalah yang dikeluhkan dapat terselesaikan. Dalam hal ini, telah terjalin suatu bentuk kerja sama percakapan antara petugas bank dan nasabahnya sehingga percakapan tersebut dapat berjalan dengan baik.

Sebaliknya, dalam kehidupan seharihari tidak jarang pula kita melihat sebuah percakapan yang berakhir dengan kericuhan misalnya saja dalam sebuah debat. Seringkali kita melihat sebuah debat yang berakhir ricuh karena percakapan tersebut sudah tidak didasari lagi prinsip kerja sama. Penutur tidak lagi melihat stuasi dan kondisi mitra tuturnya, begitupun sebaliknya sehingga menyulut emosi sehingga menjadi pertikaian.

Fenomena-fenomena dalam percakapan tersebut merupakan gambaran pentingnya prinsip kerja sama dalam percakapan yang dapat mempengaruhi keberhasilan suatu percakapan. Adanya prinsip kerja sama ini membuat seorang penutur secara tidak langsung memperhatikan situasi dan kondisi mitra tutur sehingga dapat memilih bahasa yang tepat untuk situasi dan kondisi mitra tuturnya tersebut.

Pelanggaran prinsip kerja sama ini bukan tanpa tujuan. Ada alasan-alasan tertentu yang melatarbelakangi seseorang untuk tidak menaati prinsip kerja sama percakapan. Misalnya saja, untuk mencairkan suasana percakapan yang tegang maka seseorang akan memberikan sebuah lelucon agar suasana dalam percakapan tersebut dapat berubah menjadi lebih santai. Pada prinsipnya hal tersebut telah melanggar prinsip kerja sama percakapan.

Hal ini menarik untuk dikaji karena mengingat prinsip kerja sama merupakan faktor yang dapat menentukan keberhasilan sebuah percakapan, namun pada praktiknya sering sekali tidak ditaati. Terlebih jika dikaitkan dengan budaya dalam bahasa Indonesia sendiri yang mengasumsikan bahwa semakin panjang pertuturan maka akan dianggap semakin sopan. Kenyataannya ini tentu telah melanggar maksim kuantitas dalam prinsip kerja sama percakapan yang menginginkan pertuturan yang seefektif mungkin dan tidak bertele-tele. Kesantunan berbahasa dan konteks penggunaan bahasa inilah yang menjadi faktor yang melatarbelakangi terjadinya pelanggaran prinsip kerja sama percakapan, khusus dalam bahasa Indonesia.

Pelanggaran terhadap prinsip kerja sama percakapan ini sering kita temui dalam percakapan sehari-hari, baik dalam percakapan formal maupun nonformal. Pelanggaran-pelanggaran tersebut bisa ditemukan dimana saja, kapan saja, dan oleh siapa saja dalam sebuah percakapan. Dari percakapan di warung kopi, sampai percakapan dalam sebuah debat di gedung DPR, bahkan dalam sebuah talk show yang sering tayang di televisi. Salah satu talk show tersebut yaitu Mata Najwa. Mata Najwa adalah sebuah acara talk show di stasiun televisi nasional, yaitu Metro TV. 
Mata Najwa merupakan suatu acara yang berisikan dialog anatara Najwa Shihab dengan narasumbernya dengan topik yang diangkat berbeda-beda setiap episodenya. Menggunakan bahasa Indonesia yang formal dan diisi oleh narasumber dari berbagai kalangan mulai dari pejabat hingga rakyat biasa sekalipun.

Dipilihnya Mata Najwa sebagai objek penelitian ini karena dalam dialog antara Najwa dan narasumbernya ditemukan pelanggaran-pelanggaran prinsip kerja sama percakapan. Misalnya, narasumber talk show Mata Najwa sering kali memberikan informasi melebihi yang dibutuhkan. Selain itu, untuk menggali informasi dari narasumbernya, Najwa seringkali memberikan pertanyaanpertanyaan yang memicu narasumbernya melakukan pelanggaran terhadap prinsip kerja sama percakapan ini.

Dalam penelitian ini perlu adanya rumusan masalah untuk menentukan arah penelitian. Rumusan masalah yang digunakan dalam penelitian ini yaitu:

1) Bagaimana bentuk pelanggaran prinsip kerja sama percakapan dalam acara Mata Najwa di Metro TV?

2) Faktor apa yang melatarbelakangi pelanggaran terhadap prinsip kerja sama percakapan dalam acara Mata Najwa di Metro TV?

\section{METODE}

Penelitian tentang penerapan dan pelanggaran prinsip kerja sama dalam acara Mata Najwa di Metro TV ini merupakan penelitian deskriptif dengan menggunakan pendekatan kualitatif. Djadjasudarma, (1993:8) mengatakan bahwa penelitian deskriptif bertujuan untuk membuat deskripsi, yaitu membuat gambaran, lukisan secara sistematis, faktual, dan akurat mengenai data, sifatsifat, serta hubungan fenomena yang diteliti. Penelitian ini menggunakan metode deskriptif kualitatif untuk menganalisis pelanggaran prinsip kerja sama percakapan dalam acara Mata Najwa untuk mendeskripsikan bentuk pelanggaran-pelanggaran prinsip kerja sama percakapan dan faktor-faktor yang melatabelakangi pelanggaran prinsip kerja sama percakapan dalam acara Mata Najwa.

Sumber data dalaam penelitian ini adalah video talk show Mata Najwa. Data dalam penelitian ini adalah percakapan (tuturan atau dialog) antara Najwa Shihab dan narasumbernya pada tiga episode dalam acara Mata najwa pada bulan Juni, Agustus, dan Desember yaitu: episode "Kontroversi Luhut" yang tayang pada 1 Juni 2016,"Rupa-Rupa Pengacara" yang tayang pada 31 Agustus 2016, dan episode "Bergerak Demi Hak" yang tayang pada 21 Desember 2016.

Teknik pengumpulan data yang digunakan dalam penelitian ini menggunakan teknik dokumentasi. Menurut Sudaryanto (1988: 133) teknik dokumentasi adalah teknik pengambilan data dengan mencari data yang telah ada. Dalam penelitian ini data adalah pelanggaran prinsip kerja sama percakapan dalam acara Mata Najwa. Dokumen berupa video Mata Najwa, kemudian ditransikripsikan dalam bentuk tulisan. Langkah-langkah analisis data dalam penelitian ini adalah (1) mentranskripsi data; (2) mengidentifikasi data (pengkodean); (3) mengklasifikasi data dalam bentuk tabel; (4) menginterpretasi data; (5) validasi data; dan (6) menyimpulkan hasil temuan.

\section{HASIL DAN PEMBAHASAN}

1. Bentuk Pelanggaran Prinsip Kerja Sama Percakapan dalam Acara Mata Najwa di Metro TV

Hasil penelitian menunjukkan bahwa dalam acara Mata Najwa di Metro TV terdapat pelanggaran prinsip kerja sama 
percakapan. Pelangaran-pelanggaran tersebut terkait 4 maksim yaitu, maksim kuantitas, maksim kualitas, maksim, relevansi dan maksim cara. Pelanggaran terhadap maksim kuantitas terjadi ketika peserta tutur memberikan informasi yang kurang ataupun berlebihan dari yang dibutuhkan oleh mitra tuturnya. Pelanggaran maksim kualitas terjadi ketika peserta mengatakan sesuatu yang tidak sesuai dengan fakta dan bukti yang ada. Pelanggaran terhadap maksim relevansi terjadi ketika peserta tutur memberikan informasi yang tidak sesuai atau tidak relevan dengan topik percakapan. Pelanggaran terhadap maksim cara terjadi ketika peserta tutur memberikan informasi yang tidak jelas dan ambigu sehingga menimbulkan ketaksaan. Faktor yang mempengaruhi pelanggaran-pelanggaran tersebut adalah kesantunan berbahasa dan konteks penggunaan bahasa.

Dari tiga episode Mata Najwa yaitu episode "Kontroversi Luhut" yang tayang pada 1 Juni 2016, "Rupa-Rupa Pengacara" yang tayang pada 31 Agustus 2016, dan episode "Bergerak Demi Hak" yang tayang pada 21 Desember 2016, ditemukan 130 pelanggaran prinsip kerja sama percakapan dari 101 data pertuturan. Pelangaranpelangaran prinsip kerja sama percakapan tersebut dengan rincian, 56 (43\%) pelanggaran maksim kuantitas, 10 (7,8\%) pelanggaran maksim kualitas, 34 (26,5\%) pelanggaran maksim relevansi, dan 30 $(22,6 \%)$ pelanggaran maksim cara.

Pelanggaran terbanyak yaitu pelanggaran terhadap maksim kuantitas (43\%). Narasumber di acara Mata Najwa sering memberikan informasi yang berlebihan. Pertanyaan Najwa yang sering dijawab secara bertele-tele oleh mitra tuturnya (narasumber). Hal ini dikarenakan mitra tutur Najwa (narasumber) ingin memberikan informasi yang jelas dan detail tetang topik yang sedang dibicarakan, sehingga peserta tutur dalam acara Mata Najwa akan memaksimalkan berbicara seinformatif mungkin, sehingga melanggar maksim kuantitas.

Pelanggaran paling sedikit yaitu pelanggaran maksim kualitas (7,8\%). Hal tersebut dikarena percakapan peserta tutur disiarkan melalui stasiun televisi nasional yang memungkinkan untuk dilihat oleh masyarakat Indonesia, bahkan di luar Indonesia sehingga peserta tutur dalam acara Mata Najwa meminimalkan berbicara tidak sesuai fakta dan bukti yang dapat melanggar maksim kuantitas. Sebaliknya, peserta tutur dalam acara Mata Najwa akan memaksimalkan berbicara seinformatif mungkin, sehingga melanggar maksim kuantitas.

Berdasarkan penelitian yang telah dilakukan dari 101 data tuturan pelanggaran prinsip kerja sama percakapan dalam acara Mata Najwa, terdapat pelanggaran lebih dari satu maksim secara bersamaan dalam satu tuturan. Adanya fenomena ini, maka dalam penelitian ini digolongkan atas dua pelanggaran maksim, yakni maksim tunggal dan makim ganda. pelanggaran prinsip kerja sama percakapan dalam acara Mata Najwa, digolongkan atas 75 tuturan dengan pelanggaran maksim tunggal dan 26 tuturan dengan pelanggaran maksim ganda. Pelanggaran maksim tunggal berupa, (a) pelanggaran maksim kuantitas, (b) pelanggaran maksim kualitas, (c) pelanggaran maksim relevansi, (d) pelanggaran maksim cara. Dengan rincian: 40 tuturan melanggar maksim kuantitas, 8 tuturan melanggar maksim kualitas, 16 tuturan melanggar maksim relevansi, dan 11 tuturan melanggar maksim cara.

Pelanggaran maksim ganda berupa,(a) pelanggaran maksim kuantitas dan maksim kuanlitas. (b) pelanggaran maksim kuantitas dan maksim relevansi, (c) pelanggaran maksim kuantitas dan maksim cara, (d) pelanggaran maksim relevansi dan maksim cara, dan (e) pelanggaran maksim 
kuantitas, maksim relevansi dan maksim cara. Dengan rincian: 2 tuturan melanggar maksim kuantitas dan maksim kualitas, 7 tuturan melanggar maksim kuantitas dan maksim relevansi, 5 tuturan melanggar maksim kuantitas dan maksim cara, 9 tuturan melanggar maksim relevansi dan maksim cara, dan 3 tuturan melanggar maksim kuantitas, maksim relevansi, dan maksim cara.

\section{Faktor yang Melatarbelakangi Pelanggaran Prinsip Kerja Sama Percakapan dalam Acara Mata Najwa di Metro TV}

Selain mendeskripsikan pelanggaran prinsip kerja sama percakapan dalam acara Mata Najwa, dalam penelitian ini juga mendeskripsikan faktor yang melatar belakangi pelanggaran tersebut. Faktor yang mempengaruhi pelanggaranpelanggaran tersebut adalah kesantunan berbahasa. Berikut disajikan tabel faktorfaktor yang melatarbelakangi pelanggaran prinsip kerja sama percakapan dalam acara Mata najwa di Metro TV.

Faktor yang melatarbelakangi pelanggaran prinsip kerja sama percakapan terbanyak adalah penaatan maksim kemufakatan dan penyelamatan muka. Pelanggaran maksim kuantitas dilatarbelakangi 7 faktor, yaitu: penaatan maksim kebijaksanaan, maksim kemufakatan, maksim kesederhanaan, maksim kedermawanan, maksim penghargaan, maksim kesimpatian, dan penyelamatan muka. Pelanggaran maksim kualitas dilatarbelakangi 4 faktor, yaitu: penaatan maksim kemufakatan, maksim kesimpatian, konsep muka negatif dan penyelamatan muka. Pelanggaran maksim relevansi dilatarbelakangi 7 faktor, yaitu: penaatan maksim kemufakatan, maksim kesederhanaan, maksim kesimpatian, maksim kedermawanan, maksim penghargaan, konsep muka negatif dan penyelamatan muka. Pelanggaran maksim cara dilatarbelakangi 7 faktor, yaitu: penaatan maksim kemufakatan, maksim kesederhanaan, maksim kebijaksanaan, maksim kesimpatian, maksim penghargaan, konsep muka negatif dan penyelamatan muka.

Berikut ini pembahasan pelanggaranpelanggarn prinsip kerja sama percakapan dalam acara Mata Najwa di Metro TV. Dalam pembahasan ini dibagi atas dua yaitu pelanggaran maksim tunggal dan pelanggaran maksim ganda. Pelanggran terhadap satu maksim dalam satu tuturan disebut pelanggran maksim tunggal, sedangkan pelanggaran terhadap lebih dari satu maksim dalam satu tuturan disebut maksim ganda.

\section{Pelanggaran Maksim Tunggal}

Pelanggaran terhadap maksim kuantitas yang terjadi dalam acara Mata Najwa salah satunya pada data D1/MJ/knvl/sg.1 berikut.

Najwa: "Terima kasih, sudah hadir di Mata Najwa. Pak Luhut saya menghargai bapak hadir, akan ada banyak pertanyaan yang sensitif. Jadi dari awal saya mau tegaskan saya bisa bertanya apa saja dan anda siap menjawab apa saja ya, Pak Luhut?"

Luhut: "Ya siap. Yang saya bisa jawab saya jawab, yang saya tidak bisa jawab tentu saya tidak bisa menjawab."

\section{(a) Konteks :}

Peserta tutur: Najwa Shihab dan Luhut Binsar Pandjaitan (Menkopolhukam)

Dalam episode ini topik yang dibahas adalah kontroversi seorang Luhut. Luhut adalah seorang Menkopolhukam di kabinet presiden Joko Widodo. la mendapat sorotan luas dari masyarakat karena kedekatannya dengan presiden, sehingga menimbulkan pandangan positif dan negatif serta banyaknya isu-isu yang berkembang dalam masyarakat. Dalam 
episode ini Luhut akan memberikan klarifikasinya atas isu-isu dan kontoversi atas dirinya. Topik yang dibahas dalam episode ini berkitan dengan bidang politik.Dalam percakapan di atas Najwa menyapa dan mengatakan, kalau nantinya ia akan bertanya apa saja terkait kontroversi Luhut diawal acara. Dan Luhut merespon pertanyaan Najwa dengan kalimat yang sedikit panjang dari informasi yang diminta Najwa dengan gaya bicara yang santai.

Dalam pertuturan di atas mitra tutur Najwa (Luhut Binsar Pandjaitan) memberikan informasi yang berlebihan. Maksim kuantitas tidak menginginkan mitra tutur meberikan informasi yang kurang maupun berlebihan. Dalam pertuturan tersebut mitra tutur Najwa (Luhut Binsar Pandjaitan) memberikan informasi yang berlebihan, dengan menjawab pertanyaan Najwa dengan jawaban yang bertele-tele. Jawaban yang bertele-tele tersebut tampak pada tuturan Luhut "Ya siap. Yang saya bisa jawab saya jawab, yang saya tidak bisa jawab tentu saya tidak bisa menjawab", sehingga tuturan Luhut ini dikatakan telah melanggar maksim kuantitas. Seharusnya, agar tidak bertele-tele dan tidak melanggar maksim ini Luhut hanya cukup menjawab "Ya siap" tanpa diikuti tuturan "Yang saya bisa jawab saya jawab, yang saya tidak bisa jawab tentu saya tidak bisa menjawab", karena menurut maksim kuantitas ini jawaban atas pertanyaan Najwa tersebut hanya dua yaitu, "siap" dan "tidak siap".

\section{(b) Faktor yang melatarbelakangi pelanggaran:}

Dalam percakapan antara Najwa dengan Luhut Binsar Pandjaitan di atas terjadi pelanggran prinsip kerja sama percakapan, yaitu maksim kuantitas. Luhut memberikan informasi yang berlebihan dan terkesan bertele-tele. Faktor yang melatarbelakangi pelanggaran tersebut Luhut ingin berhati-hati memberikan klarifikasi atas kontroversi dirinya, agar tidak terjadi kesalahpahaman yang justru menimbulkan kegaduhan di masyarakat. Selain itu, Luhut ingin menjalin komunikasi yang akrab dengan membina kecocokan dengan mitra tuturnya sehingga pertuturan dapat tetap berjalan. Hal ini sesuai dengan prinsip kesantunan, yaitu maksim kemufakatan.

\section{Pelanggaran Maksim Ganda}

Pelanggaran terhadap maksim kuantitas dan maksim relevansi yang terjadi dalam acara Mata Najwa salah satunya pada data D24/MJ/knvl/sg.3 berikut.

$\begin{array}{ll}\text { Najwa } & \text { : "Anda sendiri masih punya } \\ \text { Luhut } & \text { ambisi politik pak?" } \\ & \text { : "Saya ini, umur saya } 68 \\ & \text { tahun. Nah, sebagai } \\ & \text { seorang prajurit saya sudah } \\ & \text { capai semua apa yang saya } \\ & \text { mau. Anak istri saya baik, } \\ & \text { cucu saya juga baik-baik. Ya } \\ & \text { terus apa, saya sehat I am } \\ & \text { very healty, ya. Saya masih } \\ & \text { treatmeal 4 kali seminggu } \\ \text { Najwa } & \text { satu jam." "Sangat kaya juga pak?" } \\ \text { Luhut } & \text { :Iya, saya punya uanglah." } \\ \text { Najwa } & \text { "Hahaha... Menarik, } \\ & \text { menarik, karena saya } \\ & \text { sudah, saya ada laporan } \\ & \text { harta kekayaan Pak Luhut, } \\ & \text { nanti kita buka-bukaan." } \\ & \text { : "Boleh." }\end{array}$

\section{(a) Konteks :}

Peserta tutur: Najwa Shihab dan Luhut Binsar Pandjaitan (Menkopolhukam)

Percakapan terjadi antara Najwa dengan Luhut, Menkopolhukam. Topik yang dibahas adalah kontroversi seorang Luhut Binsar Pandjaitan. Luhut dikenal sebagai orang yang dekat dengan presiden, sehingga kedekatan ini menimbulkan kontroversi di tengah masyarakat. 
Kotroversi lainya adalah kabar yang memberitakan bahwa Luhut memiliki perusahaan di luar negeri yang tidak membayar pajak di Indonesia. Sebelum menjadi seorang Menkopolhukam, Luhut berkarir di dunia militer. selain itu luhut juga berlatarbelakang seorang pengusaha sukses. Kemudian, juga berkecimpung di dunia politik. Najwa menanyakan pada Luhut, masih adakah ambisi politik Luhut.

Maksim ini menginkan kontribusi mitra tutur yang relevan dengan topik pembicaraan. Dalam percakapan tersebut, Luhut memberikan informasi yang tidak relevan. Hal tersebut tampak pada tuturan, "Saya ini, umur saya 68 tahun. Nah, sebagai seorang prajurit saya sudah capai semua apa yang saya mau. Anak istri saya baik, cucu saya juga baik-baik. Ya terus apa, saya sehat I am very healty, ya. Saya masih treatmeal 4 kali seminggu satu jam." Selain melanggar maksim relevansi, tuturan Luhut tersebut juga telah melanggar maksim kuantitas, karena informasi yang diberikan terkesan berteletele, sehingga informasinya melebih apa yang dibutuhkan mitra tuturnya. Hal tersebut tampak dari pertanyaan Najwa yang menyakan apakah Luhut masih punya ambisi politik. Menurut prinsip maksim kuantitas jawab atas pertanyaan tersebut adalah "ya/masih" atau "tidak. Jadi, dalam pertuturan di atas telah terjadi 2 pelanggaran maksim secara bersamaan, yaitu maksim kuantitas dan maksim relevansi.

\section{(2) Faktor yang melatarbelakangi pelanggaran:}

Dalam percakapan antara Najwa dengan Menkopolhukam, Luhut Binsar Pandjaitan di atas terjadi pelanggran prinsip kerja sama percakapan, yaitu masksim kuantitas dan maksim relevansi. Luhut memberikan informasi yang berlebihan dan tidak relevan. Faktor yang melatarbelakangi pelanggaran tersebut terkait prinsip kesantunan berbahasa karena Luhut telah menaati maksim kesederhanaan. Ketika ditanya Najwa "Sangat kaya juga pak?" Luhut tidak menjawab iya secara langsung melainkan dengan tuturan yang lebih santun "lya, saya punya uanglah."Tujuannya adalah dapat bersikap rendah hati dengan cara mengurangi pujian terhadap dirinya sendiri. Selain itu, Luhut ingin menciptakan pertuturan yang komunikatif dengan mitra tuturnya sehingga pertuturan dapat tetap berjalan.

\section{PENUTUP \\ Kesimpulan}

Berdasarkan hasil penelitian yang telah dilakukan mengenai pelanggaran prinsip kerja sama percakapan dalam acara Mata Najwa dapat disimpulkan bahwa ditemukan pelanggaran prinsip kerja sama percakapan. Pelanggaran prinsip kerja sama percakapan tersebut digolongkan atas 75 tuturan dengan pelanggaran maksim tunggal dan 26 tuturan dengan pelanggaran maksim ganda, dengan faktor yang melatarbelakangi yaitu konteks penggunaan bahasa dan kesantunan berbahasa. Pelanggaran maksim tunggal berupa, (a) pelanggaran maksim kuantitas, (b) pelanggaran maksim kualitas, (c) pelanggaran maksim relevansi, dan (d) pelanggaran maksim cara. Pelanggaran maksim ganda berupa, (e) pelanggaran maksim kuantitas dan maksim kualitas, (f) pelanggaran maksim kuantitas dan maksim relevansi (g) pelanggaran maksim kuantitas dan maksim cara, (h) pelanggaran maksim relevansi dan maksim cara, dan (i) pelanggaran maksim kuantitas, maksim relevansi dan maksim cara.

Dari tiga episode Mata Najwa yaitu episode "Kontroversi Luhut" yang tayang pada 1 Juni 2016, "Rupa-Rupa Pengacara" yang tayang pada 31 Agustus 2016, dan episode "Bergerak Demi Hak" yang tayang pada 21 Desember 2016, ditemukan 130 
pelanggaran prinsip kerja sama percakapan dari 101 data pertuturan dengan faktorfaktor yang melatarbelakangi pelanggaran prinsip kerja sama percakapan dalam acara Mata Najwa di Metro TV, yaitu: penaatan maksim kebijaksanaan, maksim kemufakatan, maksim kesederhanaan, maksim kedermawanan, maksim penghargaan, maksim kesimpatian, konsep muka negative dan teori penyelamatan muka. Faktor yang melatarbelakangi pelanggaran terbanyak adalah penaatan maksim kemufaktan dan penyelamatan muka.

\section{Saran}

Penelitian ini membahas mengenai pelangaran prinsip kerja sama percakapan dalam acara Mata Najwa. Penelitian ini tentang pelangaran prinsip kerja sama percakapan ini hanya terbatas pada faktor yang melatarbelakangi pelanggaran terkait konteks penggunaan bahasa dan kesantunan berbahasa. Penulis mengharapkan terdapat penelitian selanjutnya mengenai pelangaran prinsip kerja sama percakapan dengan faktor yang melatarbelakangi pelanggaran yang berbeda sehingga dapat ditemukan pelanggaran-pelangaran prinsip kerja sama percakapan dengan faktor yang melatarbelakangi berbeda pula.

\section{DAFTAR PUSTAKA}

Chaer, Abdul dan Leonie Agustina. 2010. Sosiolinguistik Perkenalan Awal. Jakarta: Rineka Cipta.

Dardjowidjojo, Soenjono. 2005. Psikolinguistik: Pengantar Pemahaman Bahasa Manusia. Jakarta: Yayasan Obor Indonesia.

Djadjasudarma, Fatimah. 1993. Metode Linguistik. Bandung: PT Eresco.

Rahardi, R. Kunjana. 2005. Pragmatik Kesantunan Imperatif Bahasa Indonesia. Jakarta: Erlangga.

Sudaryanto. 1988. Metode Linguistik. Yogyakarta: Gadjah Mada University Press.

Wijana, I Dewa Putu dan Muhammad Rohmadi. 2009. Analisis Wacana Pragmatik Kajian Teori dan Analisis. Surakarta: Yuma Pustaka. 